\title{
Mobility, Access and the Value of the Mabopane Station Precinct
}

\author{
Ngaka Mosiane ${ }^{1}$ (D)
}

Accepted: 8 November 2021 / Published online: 29 January 2022

(C) The Author(s), under exclusive licence to Springer Nature B.V. 2021

\begin{abstract}
Although mobility shapes the material landscape, for the majority of ordinary people, their movements are structured by space. For this reason, ordinary people bear the bodily and financial costs of commuting to the metropolitan core areas from their peripheries. In particular, the city's core areas and peripheries are shaped by privatisation, racism and other forces of change, each driving urban change in particular, complementary ways (Pierce and Lawhon, 2018; Czegledy, 2004). That said, there are interpretations that the city's core areas are multiple and shifting, with their peripheries being unstable and indeterminable. In this sense, the city's peripheries do not always coincide with the spatial distribution of marginality and deprivation (Pieterse, 2019). Howe's (2021) idea of popular centralities through popular agency may in some ways be seen to transcend these diverging accounts of the city's uneven spatial structure. This paper uses the case of the Mabopane Station precinct in northern Tshwane to give content to this transcending idea of popular centralities. With respect to popular agency, Coe and Jordhus-Lier's (2010) forms of agency (resilience, reworking and resistance) are useful for further analysing the resilience of the residents and commuters of northern Tshwane. The paper demonstrates some of the ways through which popular centralities are constituted-how movement becomes space; and also that it is in specific places (which are always constituted by the local and the elsewhere) where resilience is exercised in ways that perpetuate and even overcome peripherality. In this sense, the paper treats a social and cultural context seriously, highlighting ordinary people's cautious uses of and intuitive, creative reuses of peripheral spaces as they turn some of them into urbanisms of self-realisation.
\end{abstract}

Keywords Agency $\cdot$ Periphery $\cdot$ Mobility $\cdot$ City-region $\cdot$ Mabopane Station precinct $\cdot$ Accessibility

Ngaka Mosiane

ngaka.mosiane@gcro.ac.za

1 Gauteng City-Region Observatory, University of Johannesburg, University

of the Witwatersrand, Johannesburg, Gauteng, South Africa 


\section{Introduction}

Mobility shapes the material landscape, but for the majority of ordinary people, ${ }^{1}$ mobility is conditioned by space; not without the ordinary people adapting, reworking or even resisting the structuring of their mobility. The actions of adapting, reworking and resisting are forms of agency elaborated by Coe and Jordhus-Lier (2010) (also see Katz, 2004). Although they are all broadly important for this paper, I specifically rely on the resilience form of agency. Resilience is variously a subject matter in the discussions of the city-region's core-periphery features. This subject matter is often framed in terms of ordinary people bearing the brunt of the city's spatial structure as they commute to and from the metropolitan core areas (Peberdy, 2017). That mobility-demanding a lot from commuters' bodies and finances-is discussed in the context of neoliberalism. Neoliberalism shapes the metropolitan core areas and peripheries, with privatisation, racisms and other forces of change driving the urban form in a particular ways (Czegledy, 2004; Pierce \& Lawhon, 2018).

Nonetheless, there are accounts that the city's core areas are multiple and shifting, with its peripheries being unstable and indeterminable (Pieterse, 2019). In this sense, the city's peripheries do not always coincide with the spatial distribution of marginality and deprivation. Howe's (2021) ideas of popular centralities through popular agency are useful offerings to these conversations, signalling an exercise of resilience in those space-making efforts. She presents popular centralities as alternatives to the state's socio-technical transport infrastructure, including the transitoriented development approach. This paper places those socio-technical interventions at the heart of the conjectural popular centralities. It gives content to popular centralities, also demonstrating that it is in specific places-which are always constituted by the local and the elsewhere-where resilience is exercised, with the result that peripherality is both perpetuated and overcome. Peripherality is perpetuated by ordinary people's resourcefulness as they adapt to their socio-spatial, economic and political conditions (Coe \& Jordhus-Lier, 2010). The paper contributes to this work, acknowledging that these mobility-based strategies (popular centralities) by popular agency can lead to highly significant changes in ordinary people's lived experiences. It pays a closer attention to their socio-spatial and cultural context to highlight their urbanisms of self-realisation-a spatial culture where local residents are being resourceful to not only survive but to make meaningful improvements in their lives, and pursue their aspirations (Gastrow, 2016); a spatial culture where informal planning, housing and livelihoods are realised on the fault lines of, while also mimicking, formal land uses, modern, suburbia-style architecture and other such activities. Notwithstanding Harvey's (2000) scepticism, the role of the cautious uses of and intuitive, creative reuses of peripheral spaces is not insignificant in these mobilitybased strategies (Robinson, 2004).

The style of the discussions in this paper is one of 'thick descriptions' as I depict some of the constituent elements of popular agency and popular centralities. The

\footnotetext{
${ }^{1}$ I use the term ordinary people to refer to informal workers, domestic and agricultural labourers as well as the unemployed people in general.
} 
paper's research materials are part of the larger project on the 'landscapes of peripheral and displaced urbanisms' (Mosiane, et al., forthcoming). The data for the latter included quantitative household surveys, qualitative household interviews and spatial datasets gathered from August 2017 to December 2019. For this paper, the research materials are focused on Mabopane, Winterveld and Soshanguve, where leaders of political and civic organisations, as well as the youth connected to the Mabopane Station precinct, were also interviewed. The participants in the survey and interviews were between the ages of 18 and 60. They variously completed primary, middle or high school education. Some of them hold Close Corporation certificates, with Technical and Vocational Education and Training as well as work experiences in fields such as building and plumbing. The total population of the focus area (Mabopane Station precinct) is 29,494 people (StatsSA 2011). A statistically significant number of 110 household members participated in the household survey, and the goal of reaching a 'saturation point' in the qualitative interviews was reached. This is a point where qualitative interview participants are beginning to give repeated responses. The paper begins by attending to the ideas of mobility as space and space as mobility. These ideas are useful for appreciating the inextricable relationship between mobility and space. The paper then introduces northern Tshwane as a space of mobility, with Mabopane Station repositioning itself as an emergent nerve-centre of the sub-regional economy. The paper then begins to elaborate on the constituent elements of popular agency and popular centralities; first the hardships of mobility in the sub-region hinged around the Mabopane Station precinct, which also offers socio-economic opportunities. The concluding remarks recap the key assertions of the paper, also mainly reflecting on the possibilities that can be effected to reduce the precinct's hardships and bolster its socio-economic prospects.

\section{Mobility as Space}

Movement is one of the forces that shape the material landscape in that the global nodes of mobility have inspired the creation of airports, for example, as spaces of unimpeded movements through specialised immigration points; the introduction of discount voyager packages as well as lounges for massages, comfort and pampering (Cresswell, 2006). In other localised contexts, those kinds of unrestricted movements take the forms of religious pilgrimage for one's self-scarifies; a traditional walk to a monument; or a walk through a scenic park for self-replenishing. These unhindered movements can also be expressed artistically through practices of pedestrianism-as an exploration of one's relationship with a landscape and with the world as well as a walk for self-expression, free from the structuring features of the built environment (Cresswell \& Merriman, 2011). That said, the spaces of mobility shape most travellers into submissive subjects of mobility (Chikengezha \& Thebe, 2021), an exercise of power that is often met with adaptability and resistance (Katz, 2004; Watts, 2015). Accordingly, Coe and Jordhus-Lier (2010) embed the labour agency in its scalar, spatial and temporal contexts in their discussion of the geography of labour. They argue that labour agency is always relational, with its potential to 
effect change being contingent on its capacity to engage structures of power at different points in the global production networks. The net effect of this geography of labour is that labour agency is differentiated along the lines of not only resilience, reworking or resistance, but also of ideological, class and other categories of difference.

Coe and Jordhus-Lier's (2010) forms of agency are useful for this paper as they can be applied to the discussions on the subjects, spaces and practices of mobility. In that sense, the actions of commuters and residents living near a space of mobility may materially rework their lived experiences; improving-not undoing- those conditions. Their interaction with those in power may alter the relations between them for better terms and conditions within an existing political economy framework (ibid). The same issues attended to at the intermediate, meso-level of engagement, commuters and residents would be conscious of their positions as multiple subjectivities, who can engage the dominant structures along the lines of their class, gender, racialized, religious, ethnicity and other categories of difference (Cresswell, 2006). In this sense, they intentionally seek to challenge their social relations through attempts to variously regain control over the infrastructures of transport (Coe \& Jordhus-Lier, 2010). As macro-level political citizens, the commuters and residents will seek to correct—on social justice terms - the existing socio-economic and political relations (Coe \& Jordhus-Lier, 2010). These forms of agency (reworking and resistance) are broadly important in this paper, although I specifically rely on the resilience form of agency. In the commuters of the former bantustans in South Africa being resilient, during and after apartheid, they resigned to the resilience of the apartheid infrastructure (rail and road), as they bear the responsibility of adapting to those conditions. In this way, they have become responsibilised subjects through the state's neoliberal techniques highlighted below (Watts, 2015; Ferguson, 2009). Resilience is largely expressed individually, with subjects just getting by without changing their everyday realities. Indeed, their actions may lead to some incremental changes in their lived experiences. This paper takes seriously the resilient actors' "location in particular social and cultural landscapes" as their actions tend to deliver more substantial gains than envisaged by Coe and Jordhus-Lier (2010: 12). The section below attends to one of these social and cultural landscapes, where Howe (2021) seems to be similarly underplaying the potential for her ideas of popular agency and popular centrality.

\section{Space of Mobility}

The material landscape - as a social relation - shapes mobility, especially in contexts where a city space is designed to engineer racial, ethnic, and/or class outcomes. Indeed, the spatial structure of the apartheid city or city-region persists in 2021 (Ballard et al., 2021), albeit based more on class than race. That uneven spatial structure was further consolidated in 1996 through the adoption of the Growth, Employment and Redistribution (GEAR) ${ }^{2}$ macro-economic strategy. Although the

\footnotetext{
${ }^{2}$ GEAR is a pro-market macro-economic strategy in South Africa, although there is little consensus on whether GEAR replaced the Reconstruction and Development Programme (RDP) or it is designed to engender economic stability as a way of supporting RDP (an interventionist, state-led national development programme adopted in 1994 in this country).
} 
state's expenditure on ordinary people's housing, universal public services and other interventions has been significant since 1994, arguments are being made that much of that state's expenditure has gone to private capital and transnational elites (Maharaj et al., 2011; McDonald, \& Pape, 2002; McDonald, \& Ruiters, 2005; Ruiters, 2011). For McDonald (2008), the latter have received huge tax breaks as well as government-sponsored loans for infrastructure on municipal services, telecommunications, housing, roads, railways, ports, harbours, entertainment and convention facilities. The effects of these disproportionate state and private expenditures reproduce the city in particular ways. The supply of jobs, goods and services come to be concentrated in the city's core areas, at the expense of the peripheries (Royston \& Budlender, 2016; Eriksson and Malmberg, 2008). Indeed, Table 1 shows that in 2016, the share of economic activity was high in Pretoria central ${ }^{3}$ and Brooklyn, where GVA totalled R36 314 million. This comprised 3\% of the Gross Value Added (GVA) of the extended Gauteng City-Region (GCR) (a radius of $175 \mathrm{~km}$ from the centre of Johannesburg). However, it had only $1 \%$ of this region's population $(1.243 \%)$. In contrast, the combined GVA share for Mabopane, Soshanguve, and Winterveld was far less $(1.382 \%)$ relative to their joint population share $(2.63 \%)$.

In this kind of neoliberal investment patterns, the ordinary people end up bearing the bodily and financial costs as they commute to and from the metropolitan core areas (Author, et al., 2018). Broadly, neoliberalism structures the metropolitan core areas, with privatisation seen as a significant driver of urban change. In South African cities, the public spaces are being privatised through the gating of housing estates, extended by de facto to front areas of private property - that is, the municipal areas along the state's streets and pavements (Czegledy, 2004). Similarly, the tolling of roads and transport infrastructure to the newly built suburbs, commercial and industrial areas are being corporatised, at the expense of the low income class. The road and rail infrastructure to these areas mainly serve the middle- and higher income classes who can pay higher fares or afford to use their own private vehicles (Czegledy, 2004). Added to this class experience, Pierce and Lawhon (2018) highlight the racial prejudices against the people of colour in a North American context.

Despite these accounts of peripheralisation, scaled spatial divisions and the erosion of the public, there are arguments that the relationship between deprivation and urban space is fluid, dynamic, and strategic and has little to do with the distance between places of work in the city's core areas and their homes in their peripheries (Pieterse, 2019). For him, the city core areas are multiple and shifting, while its peripheries are unstable and indeterminable. In this sense, the city's peripheries do not always coincide with the spatial distribution of marginality and deprivation. Reflecting in this 'spatiality of poverty', Howe (2021) highlights the 'popular agency' (people making choices and strategies as they move through the local and regional spaces in pursuit of opportunities); in the process producing the transversal,

\footnotetext{
3 The name Pretoria is used in this paper to refer to the pre-1994 municipal boundary of the former White residential and commercial areas, while the name Tshwane or the City of Tshwane are henceforth used to stand for the City of Tshwane Metropolitan Municipality. That is, Pretoria continues to be used as the place name-as opposed to the name of the municipal area containing it - for the urban extent that is South Africa's capital city, the seat of the executive arm of government.
} 
Table 1 Share of GVA and population per mesozone. Source: StepSA CSIR Mesozones

\begin{tabular}{llllll}
\hline Mesozone & $\begin{array}{l}\text { Total GVA } \\
(\mathrm{R} \text { million) } *\end{array}$ & $\begin{array}{l}\text { Share of GVA } \\
\text { for GCR }(\%)\end{array}$ & Population & $\begin{array}{l}\text { Share of popula- } \\
\text { tion for GCR }(\%)\end{array}$ & $\begin{array}{l}\text { Difference between } \\
\text { GVA and population } \\
(\%)\end{array}$ \\
\hline Soshanguve & 5167 & 0.493 & 242000 & 1.288 & -0.794 \\
Mabopane & 9550 & 0.794 & 152000 & 0.810 & -0.014 \\
Winterveld & 1548 & 0.095 & 99800 & 0.532 & -0.437 \\
$\begin{aligned} \text { Pretoria central } \\
\text { and Brooklyn }\end{aligned}$ & 36314 & 2.944 & 233300 & 1.243 & 2 \\
\hline
\end{tabular}

*Excluding agriculture, forestry and fishing and mining and quarrying

'popular centralities'. Mobility is central to those strategies of resilience, including the cautious uses of and intuitive, creative reuses of peripheral spaces (Robinson, 2006). The popular centralities are produced as spaces that are alternative to the state's socio-technical transport infrastructure, including transit-oriented development. In advancing the ideas of popular agency and popular centralities, Howe (2021) ironically pushes for place-based local development initiatives such as those in Diepsloot- "strategies for fostering centralities where people live..., rather than simply transporting them to existing ones" (p. 12-13). This argument is made despite the fact that Olga "wishes the trains were still running" (p. 12) (Olga is one of her research participants). The argument about popular centralities being alternative spaces is also made despite the fact that the transversal networks of popular agency and popular centralities are part of the state's common transportation infrastructure. This paper gives content to those conjectural popular centralities, demonstrating how movement becomes space; and how it is in specific places-which are always constituted by the local and the elsewhere-where peripherality is perpetuated or may be overcome.

\section{Northern Tshwane as a Space of Mobility}

The AmaNdebele people in the pre-colonial Tshwane are an example of how traditional communities there were historically attached to chieftaincy, and thus characterised by mutual watching where people helped one another (pers. comm., local resident, 2019). Although their mobilities were closely managed, this does not mean that they were shiftless. Generally, the precolonial southern African communities had tendencies of splitting into groupings (fission) or affiliating with others (fusion) (Parsons, 1995). The result is that while some of the AmaNdebele remained in northern Tshwane, others moved to parts of what is now Mpumalanga (Middleburg, Groblesdaal and other places) (Fig. 1). Importantly, the ways of life and thinking of the people of northern Tshwane may have been tentatively rooted and bounded in places that ensured meanings and authentic existence, but their spaces have always been those of mobility. Similarly, despite the colonial and apartheid state balkanising northern Tshwane into ethnic and racial terrains (Fig. 2), the sub-region 


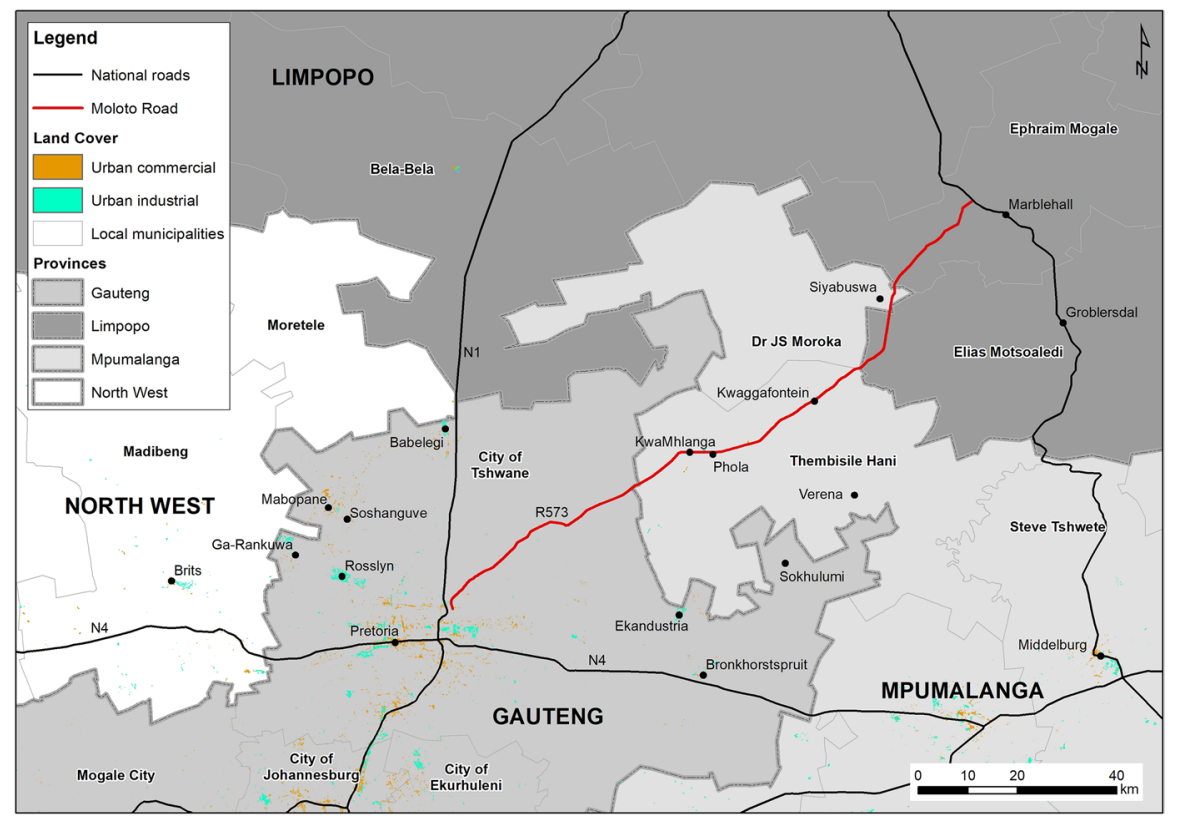

Fig. 1 Location map ofvarious places referred to in this paper. DATA SOURCE: Municipal DemarcationBoard, NGI; map by Mncedisi Siteleki, Jennifer Murray and Ngaka Mosiane

remained a common space of circulation. Accordingly, commuting to the broader Pretoria area in particular, where most of the jobs for this sub-region are located, is part of this mobility. The South African state has historically subsidised two major bus companies for this mobility-the Public Utility Transport Corporation from 1945 and, after 1977 the North-West Star, which is a subsidiary of the Northwest Transport Investments Limited (pers. comm., senior official of the North West Star, 2018). This subsidy is being sustained by the post-apartheid state (pers. comm., senior official of the Department of Transport, 2018).

This paper's interview materials reveal that northern Tshwane was also characterised during the apartheid period by its internal worker commutes to local sites of employment, with a number of smaller bus companies privately servicing other mobility needs. For example, Thari company operates the Mabopane-GarankuwaBits line; the Mathole Bus Service ferries the Tshwane University of Technology students; Jet Al is a private hire that transports local primary and high school students while Rametse Express Tours provides private hire, scholar transport and shuttle services. Thus, the contiguous Mabopane, Soshanguve, Winterveld and Garankuwa townships, established by the 1960s, are part of this displaced subregion where mobility underpins schooling, shopping, work and other forms of everyday existence. The first industries in this area were built in Rosslyn in 1960 under the national 'border industry programme'. The investors included Fiat, Datsun and Praetor Monteerders, while Alfa Romeo and other firms located nearby in the Brits area in 1974 (Fig. 1). Other industries invested in Bronkhorstspruit (Ekandustria) 


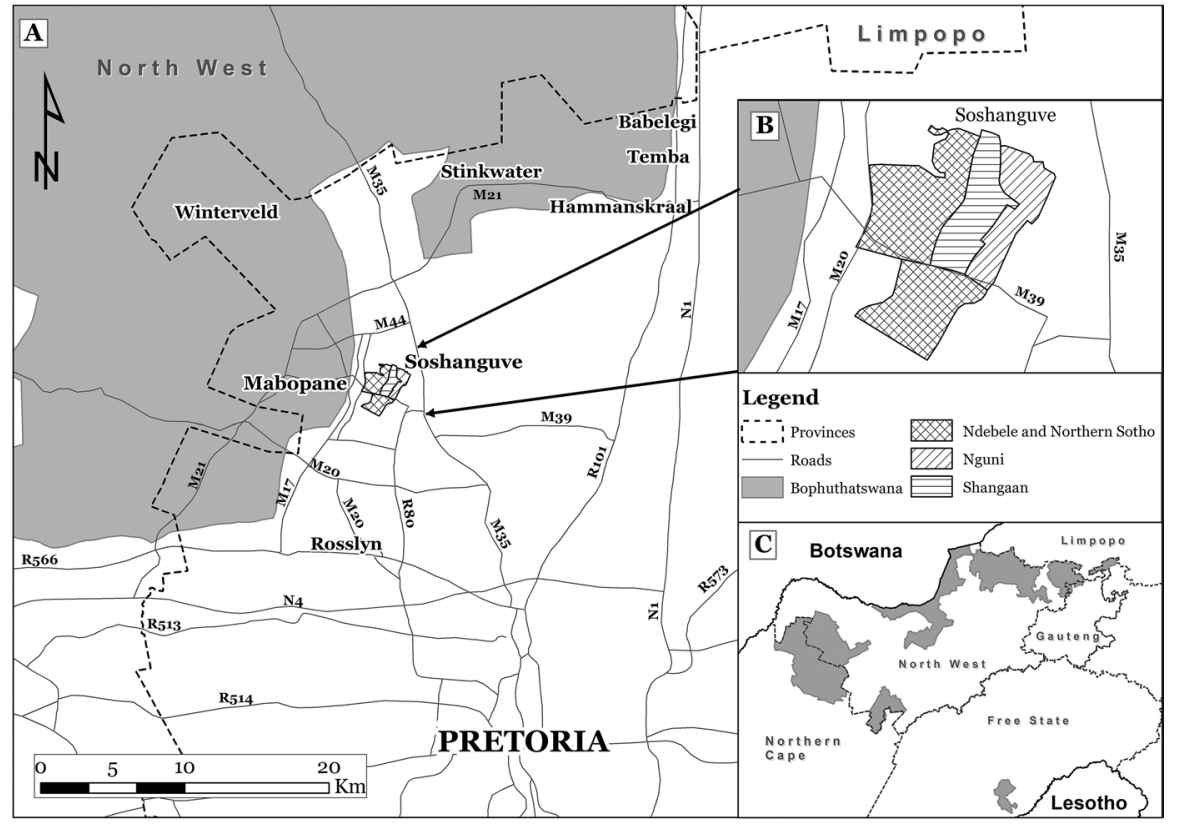

Fig. 2 Northern Gauteng andthe apartheid era contexts for Mabopane, Winterveld and Soshanguve. DATASOURCE: Author's research; map by Jennifer Murray and Ngaka Mosiane

in the 1980s (ibid). Industrial investments were incentivised to locate within $50 \mathrm{~km}$ outside the bantustans. The Babelegi industries (Fig. 2) were nationally the first to be built within the bantustans in 1970 under a national programme of 'industrial deconcentration' from the core urban centres (Harrison \& Dinath, 2017). Those industries in Garankuwa and Mabopane Unit N were built in the 1980s under the industrial programmes of the former Bophuthatswana bantustan. ${ }^{4}$ All these industrial interventions were reconfigured by the post-apartheid state, with the effect that many of the recipient industries ether relocated to the city core areas or ceased their operations.

For its part, the continuing resilience of the Rosslyn industries is linked to shifting its operations away from Taylorist methods of production. This shift to just-in-time, post-Fordist work processes and especially the restructuring of state-backed industries had a knockdown effect on the employment levels of northern Tshwane, with a significant size of the higher income class deserting to the core parts of the City of Tshwane. It is in this context of the economic and demographic shifts in northern Tshwane that the Mabopane Station precinct is

\footnotetext{
${ }^{4}$ I interviewed a number of former workers from some of these industries. One of them who worked at Dutsan plant in Rosslyn, where his work involved installing dashboard or seats. He was paid R13 per week which could rise to R250 per month when he worked overtime. The same conditions of work applied to the Nissan company, while the BMW firm paid workers R100 per week. The industries in Isithebe, Ladysmith and Newcastle (in KwaZulu-Natal) and those in Phuthaditjhaba, Qwaqwa, were built in the 1980s under this programme.
} 
repositioning itself as a key sub-regional economy. Accordingly, and as Table 1 indicates, the Mabopane Station precinct boasts of an extensive informal economy and a range of formal industrial, commercial and other service sector establishments as well as general government, community, social and personal services (Demacon, 2012). These businesses and government services draw people for work; for accessing private or government services; or for transit (Demacon, 2012). The Station precinct is also made up of the real estate developments of the Central City mall; the two different but proximate Soshanguve shopping complexes; the rental, state provided and mortgaged residential sites as well as the nearby Mabopane Unit $\mathrm{N}$ industrial areas (see Fig. 3). The Mabopane Station itself was completed in 1979, with its pedestrian bridge built over the Station to connect the ethnically divided Mabopane and Soshanguve townships (see Fig. 2). In addition to its role as a space of mobility, the railway line associated with this Station was meant to also serve as a boundary between these townships. This socio-spatial division is currently being reproduced through the designs of the Mabopane Station and that of the contracted bus services - the Public Utility Transport Corporation bus service operates in Soshanguve only, while the NorthWest Star buses service the Mabopane side only. The spatial divisions of the bus

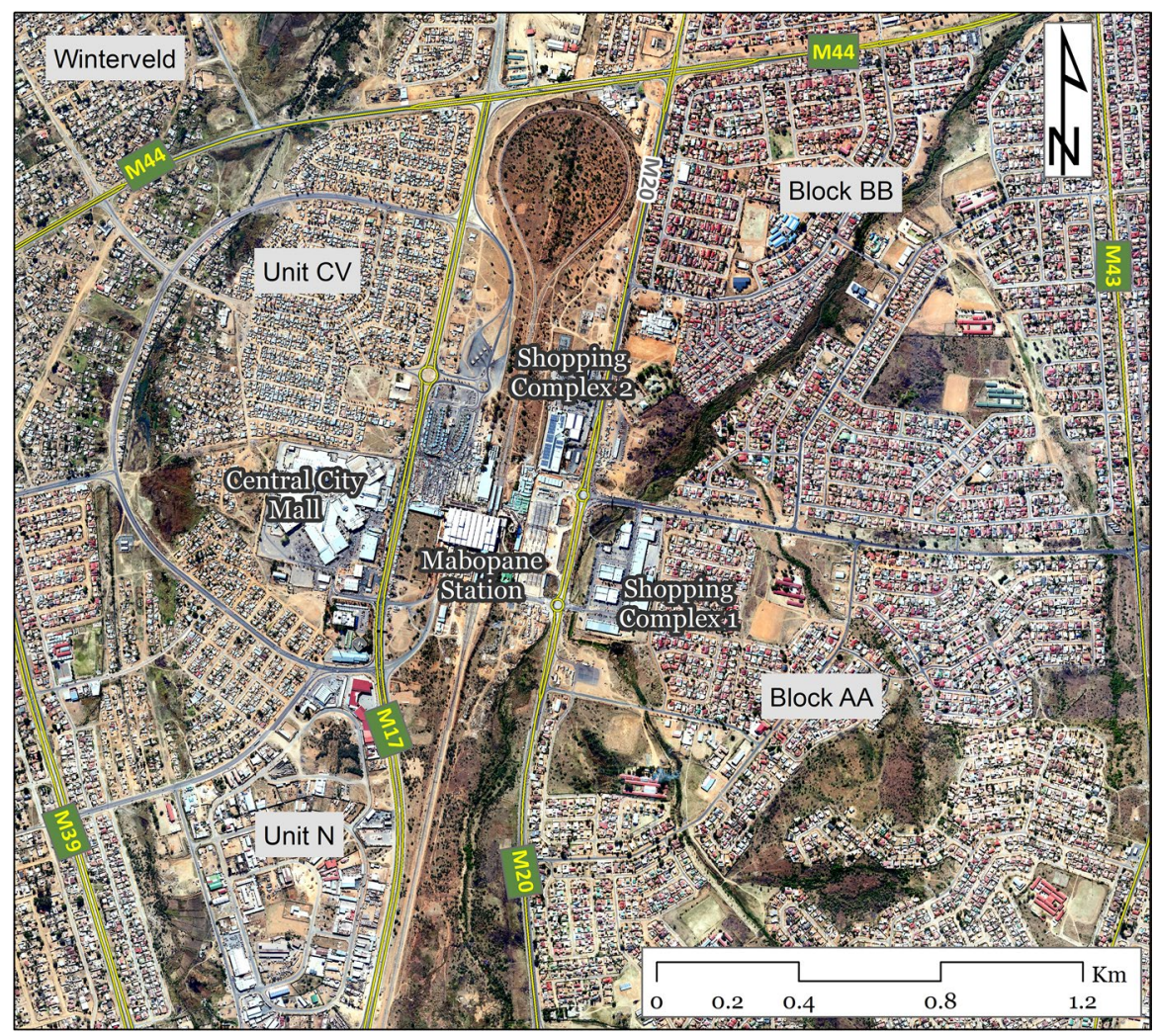

Fig. 3 Mabopane Stationprecinct. DATA SOURCE: National Geo-spatial Information; map by Jennifer Murrayand Ngaka Mosiane 
services and that of the Station precinct continue to echo the grand apartheid spatial design. The retail stores inside the Mabopane Station since its inception in 1979 were mainly formal in nature, given that informal businesses were prohibited in these kinds of state and private facilities as well as central parts of South African towns and cities.

From 1990, however, which marks one of South Africa's political sea-change, much of the Station area came to be occupied mainly by informal traders. Given that it was only the Central City shopping complex that was operational then, informal trade became a relatively lucrative business. Commuters and local residents, who supported it, assert in the interviews that they had more disposable income from working in the local industries (Babelegi, Rosslyn, Garankuwa and Mabopane) and from saving part of their incomes through shared living arrangements with family members. By the year 2000, these savings informal trade opportunities were diminished by the closure of state incentivised industries and family members increasingly opting to live separately as they take advantage of state provided housing. The shrinkage in household disposable incomes and the growth in shopping malls and complexes locally reduced the profitability of informal trading in particular, which was also being oversaturated by excessive participation in informal trade. That said, the Station precinct remains a possible nerve centre of an emergent sub-regional economy through which residents and commuters can generate household incomes by reaching different places for work and services and by carrying out socio-economic activities at the Station precinct itself. Nonetheless, it is still characterised by hardships, including those of insufficient transport connectivity.

\section{Mabopane Station Precinct and Mobility: Hardships}

The local townships, their proximate rural areas and the Mabopane Station precinct are poorly connected to the City of Tshwane core areas. The overall carrying capacity of the major M35 and R80 roads and the M39, M20, M21 and M17 roads is insufficient because of high volumes of commuting. In 2004, 228,000 people from the northern Tshwane were crossing the Magaliesberg mountains daily southwards, where most of the jobs were located (City of Tshwane, 2012; Hattingh \& Horn, 1991) (see Fig. 4). The major M35 and R80 roads pass outside the townships and are poorly connected to most train stations, while the east-west linkages (M44, Ruth First, Hebron Road and R566 roads) poorly connect the northern townships among themselves. The in-depth interviews that I conducted at this Station confirm that walking and the use of minibus taxis are the key modes of transportation locally and to Pretoria. Commuters begin their travels from home as early as $02 \mathrm{~h} 00$, walking to or taking a bus or minibus taxi to Mabopane Station, if not directly to downtown Pretoria. Although the cost of bus for a single trip locally is cheaper (R9), it takes a longer route, and hence, longer time to get to the Mabopane Station. A single trip on a minibus taxis locally cost R11, and both the bus and taxi fares double in cases of larger grocery shopping, when additional grocery seat is paid for. Despite a trip to Pretoria by minibus taxis being costlier (R22) and in spite of this mode of transport being a road safety risk, it is mostly used because it is faster and passengers 


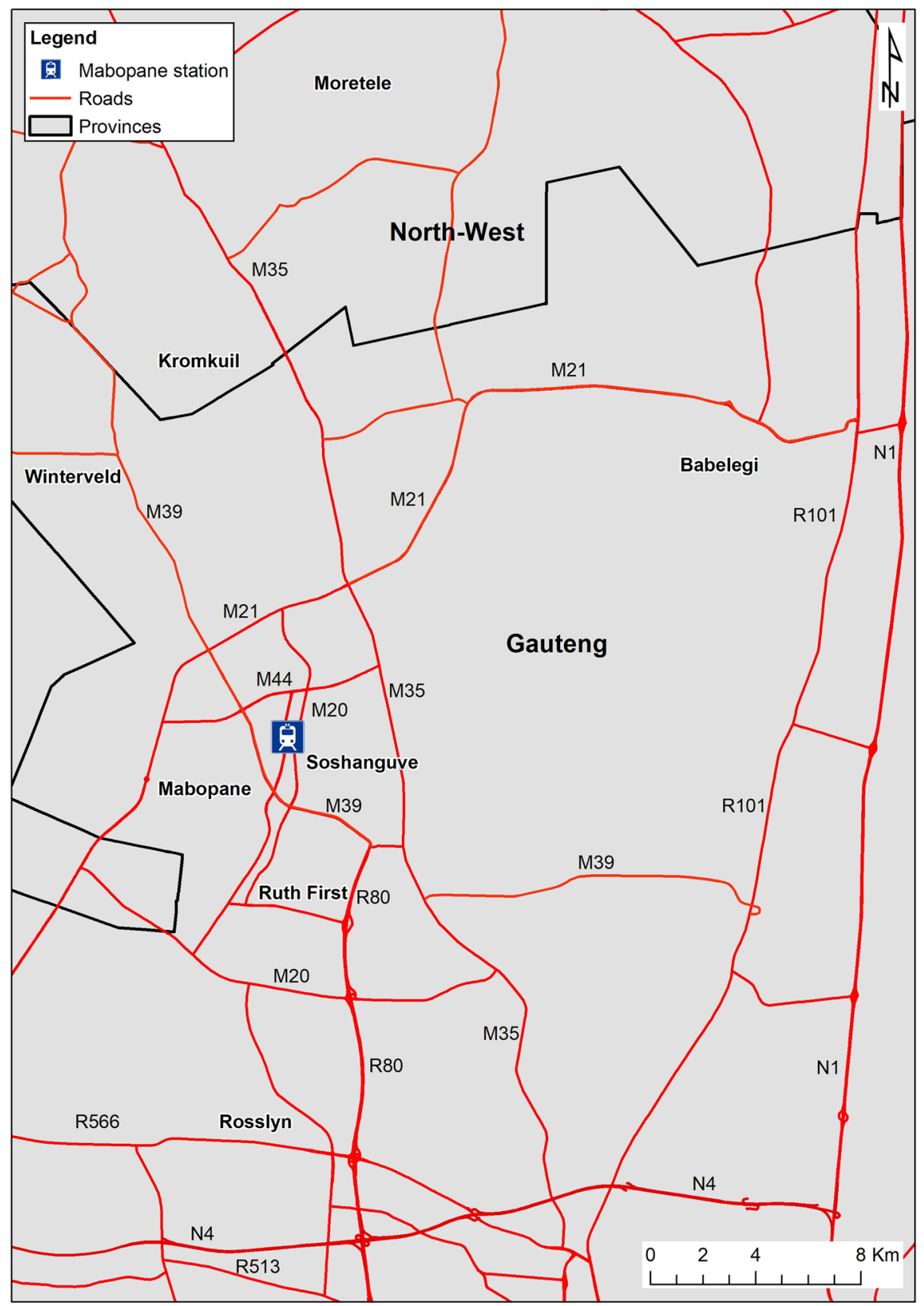

Fig. 4 Part of northernGauteng city-region road network. DATA SOURCE: National Geo-spatialInformation; map by Rethabile Sibisi, Christian Hamann and Ngaka Mosiane

can hop in and off at informal stops. A one-way journey to downtown Pretoria by bus is R20 and R8 by train. A given worker from Winterveld walks to the Station, then ride a train to downtown Pretoria (Marabastad or Bosman), and then transfers 
into a taxi at the cost of R14 to his or her workplace elsewhere in the city. The total single trip to one's place of work can be up to R33 by train, R45 by bus and R47 by taxi. The cheapest total return trip for a northern Tshwane-Pretoria commuter could cost R1 320 per month, but end up being $42 \%$ more (R1880 monthly). The costs are driven higher by passengers resorting to a faster taxi mode of transport, despite the dangers associated with it.

Mobility between Pretoria and the townships of Mabopane, Winterveld and Soshanguve is weighing heavily on commuters in term of road accidents as well as costs to their time and quality of life in general. Indeed, the Demacon (2012) study underscores the reality of extremely long daily commutes that pass through at least one major city, defining life for many people in this Gauteng city region periphery (Fig. 5). The Mabopane trains tend to 'get stuck in the middle of nowhere', with electricity and their mechanical failures variously shutting down the entire operation for a period of an hour to a week, or those failings can also lead to overcrowded trains, with passenger transferring en route to those that are operational. Buses also tend to malfunction during the trip, even though they effectively cost as much as taxis (R20). The complaints that trains often get commuters late to work and delay stocks for informal traders do not only affect local entrepreneurship and tarnish the image of commuters' areas of origin but also render residents of such areas unemployable. The unreliability of the trains and buses, and associated passenger overcrowding are linked to the lack of investments in them, resulting in the decline of their market share. The post-1994 shift in the state subsidy model for buses, from ticket-based to the one based on the distance travelled led to the drop in bus revenues. For this reason, the North-West Star reduced its fleet of 650 buses in 1985 (17 million tickets) to 255 buses in 2019 (pers. comm., official of North-West Star bus company, 2018). In 2020, the North-West Star seems to have ceased its operations, and I am unsure if it has been replaced by another operator. The state subsidy for the Passenger Rail Agency of South Africa (PRASA) has also been cut by half (pers. comm., official of PRASA, 2018). It thus reduced its rail service schedules by $20 \%$ since 2004 - out of 427 trains per day that were running in 2004, 334 were in service in 2012 (City of Tshwane, 2012) and 79 trains in 2020 according to media reports. As a result, the parastatal has embarked on revamping its train stations nationally to generate income through variously renting out space to bus companies, informal traders and formal and retail stores.

Indeed, commuters and residents variously bear the brunt of moving through this popular centrality (Pretoria-northern Tshwane, and beyond). That mobility is hinged around the Mabopane Station, for engaging with this periphery in general. For train commuters arriving back at the Station from Pretoria around $21 \mathrm{~h} 00$, local taxis have stopped operating by then, in which case commuters have to either walk home or get lift from someone. This interview response is representative of the sentiments expressed widely: "we suffer due to nyaope ${ }^{5}$ boys. While the Central City mall and the Soshanguve shopping complexes are safe, the Mabopane Station is unsafe and annoying-it is buzzing with people and informal traders such that nyaopes

\footnotetext{
5 Nyaope is a uniquely South African street drug - a cocktail of marijuana, heroin, anti-retro-viral drugs, rat poison and acid.
} 
use trading stalls to hide and rob people". The streets in the immediate vicinity of the Station are equally dangerous. The current movement between the Mabopane Central City mall and the Station requires crossing the M17 road or its intersection. The M17 pavements are inundated with informal traders and a maze of pedestrians manoeuvring to cross the roads buzzing with vehicles that do not respect pedestrians. On the Soshanguve side, a growing trend is the use of traffic circles as intersections, rather than traffic lights. They have been newly introduced on the M20 road, a busy spine motorway between the Station and the Soshanguve shopping complex 1 (Fig. 3). Accidents involving pedestrians and taxis are a common occurrence along the M20 road, leading the President of the Soshanguve Local and Long Distance Taxi Association to refer in an interview with me to many police dockets against his members. A sentiment by a granny at Mabopane Unit CV (Unit CV henceforth) represents residents and commuters who are adamant that introducing traffic lights will protect pedestrians, especially younger people. She told me that she was nearly hit by a car driving in an opposite direction on M17, a four-lane road with two lanes going in opposite directions. Luckily, she escaped when it swerved onto a pavement. In this sense, as informality becomes one of their defining features, the formal designs of the Station upgrades and associated bus and taxi ranks are already unravelling, with brim-full crowds and vehicles, incessant shouting, hooting and peddling. Pedestrianism here is about survival, unlike on the streets near some train stations in the Gauteng city-region core areas, where walkers can stop, converse, relax on street furniture or pass through (Wray, 2014).

The Station tunnels that pedestrians use to walk to the platforms and between Mabopane and Soshanguve equally pose troublesome situations. One tunnel is on the southern side of the Station, through which people walk either upstairs to the train platform or walk to the other side of the Station. The other tunnel is on the northern side, through which pedestrians walk past a labyrinth of trading stalls. From this tunnel, one can walk upstairs to the train platforms or to the other side of the Station. The third tunnel is crowded with informal traders under the M17 road on the Mabopane side. These tunnels are unlikely to be closed when the foot-bridge is completed because they have become sites for informal traders. Apart from the tunnels and foot-bridge, there is little else in the way of vehicular and pedestrian crossing the railway line within the north-south $6 \mathrm{~km}$ block of the Station. The situation has been this way from 1979 such that a group of young people playing games on an open ground in Soshanguve Block BB tells me that "this is just the way things are-we have come to be accustomed to it". Commuters and walking shoppers end up crossing the shrubby railway reserve area shown in Fig. 6.

The experiences of pedestrians walking over the M20 and M17 spine roads; walking through the passage between Soshanguve shopping complex 1 and Block $\mathrm{AA}$ as well as the passage between Mabopane Central City mall and Unit CV, specifically link the precinct's spatial design to crime exposure. Unit CV is a former squatter settlement from 1994. Although the entire Unit CV was improved-supplied with state funded housing in 2007-incidences of mugging and robbery have not subsided. The walks from Unit CV start any time after $02 \mathrm{~h} 00$ due to long queues that tend to form at the Soshanguve Block BB clinic or the social grant service point there. Those walks are often through the dark township streets, across the Station 
tunnels or the shrubby railway reserve area (Fig. 6). The people of Unit CV also use the steppes near the M17 road as the nearest entrance, down an extended tunnel, to the Central City mall. The tunnel tends to be congested during month-ends, Christmas period and Easter weekends, a condition that is conducive for yanking women's handbags. Although mugging and rape are experienced anytime of the day on the Unit $\mathrm{CV}$ and Block AA passages, winter times are even more dangerous anywhere for all pedestrians. Indeed, natural surveillance (mundane, routine precautions) is deployed as a strategy for safety (Marks \& Overall, 2015), but some pedestrians tend to look away as they are afraid of being seen 'to deny food' to muggers. Otherwise, they are likely to be followed and attacked where they live. Unit CV is also separated from the Central City mall on its north by grassy and smelly passage due to littered solid wastes and the mall's burst sewerage pipes. Waterlogging is a major problem during rainy seasons in Unit $\mathrm{CV}$, Soshanguve Block AA and the broader township areas such that pedestrians take longer, vehicular routes to get to the Station as well as the shopping centres and malls.

The Unit CV-Central City passage is also exposing pedestrians walking to the Station precinct to danger. The question is whether the removal of palisade fencing and enhancing the aesthetics of the passages and back-ends of shopping complexes and malls can improve the areas' security, walkability and socio-cultural and economic benefits? Will better lighting in these areas at night reduce pedestrians' vulnerabilities to crime? Although the long-winded walks into shopping centres are linked to palisade fences separating these spaces from nearby residential areas, the granny is opposed to the fences being brought down or to creating pedestrian gates through palisade fences at the back of shopping malls and complexes. A granny at Unit CV says "the Central City mall is rotten, and removing palisade fencing will enable the nyaopes to openly 'set up shop' on the passage areas, with Unit CV used as a hideout for stolen goods. For this reason, the police helicopters hover over Unit CV'. The younger people that I interviewed are in favour of removing palisade fencing or at least creating pedestrian gates that can be closed at $18 \mathrm{~h} 00$ or after. This is because armed robbery and the jumping of the palisade fence are happening anyway. The passage area can also be manned by security guards as "we have a person screaming from mugging and/or rape every week, and people do not have cars to take longer routes to shopping centres".

The Soshanguve shopping complex 1 is separated from the Station by the M20 road, with Soshanguve Block AA on its eastern side. This shopping complex 1 was built in 2005, and it is also separated from Block AA by a road and palisade fence. It is unsafe to walk through the north-eastern passage (Fig. 7) and the south side of the shopping complex 1 . The nyaopes tend to wait at these spots to rob pedestrians of their possessions and/or rape women. A $400 \times 300 \mathrm{~km}^{2}$ bushy area in the southern part of this Soshanguve shopping complex 1 was initially rounded up with a wire fence net. Due to the lengthy walks required to enter the shopping complex 1 from the front (western side), pedestrians who walk from the eastern side (Block AA) to the shopping complex 1 cut it down, creating a path through the bush along the palisade fence on the southern side. It is a common feature to see people walking this area and the broader neighbourhood carrying plastic bags full of grocery. Some of the pedestrians and residents recount in the interviews an experience of three 
ladies robbed in front on their house immediately behind (the eastern side of) this Soshanguve shopping complex 1 . While waiting for transport in front of their house along a dark street on a winter morning, a car without lights and number plates suddenly stopped in front of them from which gun-pointing men instructed them to lay down. The men then took the ladies' handbags containing cellphones, transport tickets and wallets. Overall, in addition to being a space of mobility, the Mabopane Station precinct has increasingly become means through which commuters and residents exercise their resilience, as they adapt to their peripheral circumstances.

\section{Resourcefulness and the Value of the Mabopane Station Precinct}

The Mabopane Station has become a resource to commuters as well as to residents of the precinct and the broader northern Tshwane as in 2012, it was used daily by about 70000 commuters as a major point of origin, transfer and destination (Demacon, 2012). The informal traders are some of the users of the Station, forging a space for themselves there as they connect their activities to the local and distant places. They start their operations from around $02 \mathrm{~h} 00$ to $09 \mathrm{~h} 00$, retreating back during offpeak hours, and resuming from around $14 \mathrm{~h} 00$ to $21 \mathrm{~h} 00$. Some of them source their stock locally from outlets such as OBC Chicken and Meat stores, while others buy their supplies from Marabastad (downtown Pretoria) twice or four times a week. See Table 2 for the kinds of goods they sell, most of which need access to electricity, water, secure refrigerated storage and customer access roads.

The informal traders tend to buy their stock in Pretoria in groups, especially those selling fruits and vegetables. They hire mini-trucks or mini-bus taxis for R350 per return trip. Informal traders in KwaMhlanga, Phola and Kwaggafontein (Fig. 1) areas also purchase their stock in Pretoria, while those in Rustenburg in the NorthWest province procure it locally because Rustenburg comparatively produces higher quantities of goods and services. As Table 1 indicates, the comparison is useful for understanding the different workings of informal trade in the Gauteng city region that is socio-economic, and politically heterogeneous. Traditional doctors are part

Table 2 Informal traders' items at Mabopane Station

\begin{tabular}{ll}
\hline Food & Fast-food, cooked food, sweets, coffee \\
\hline Non-food & Cigarettes \\
Audio/video & Animal collection, Nollywood, multimedia speakers \\
Clothes and accessories & $\begin{array}{c}\text { Traditional clothing, blankets, bags, school bags, diapers, hats, children socks, } \\
\text { belts, earrings }\end{array}$ \\
Health & $\begin{array}{l}\text { Traditional consultation and medicine (Sotho, Uganda), toilet papers } \\
\text { Household appliances } \\
\text { Padlocks, paraffin stove, plug extension cords, light bulbs, masking tapes, } \\
\text { polyvinyl chloride fittings and water taps, cast iron water taps, nail steel, } \\
\text { keys, cockroaches killing bait, mosquito repellent coils }\end{array}$ \\
Beauty & $\begin{array}{l}\text { Hair salons, manicure and pedicure } \\
\text { Services }\end{array}$ \\
& $\begin{array}{c}\text { Funeral associations, funeral services, patrols, stockvel, informal traders } \\
\text { associations }\end{array}$ \\
\hline
\end{tabular}


of the informal traders working on the street pavements of the Station precinct, with the South African practitioners identifying themselves as such-traditional doctors. They tend to eke out a living, charging R100 for a rare consultation and an associated R100 for medicine. "What shall we eat", ask a despondent female practitioner, who also receives an older persons grant per month (R1890). Notably, traditional doctors serve to anchor the lives of commuters and residents, and create a space for their spiritual selves to convivially believe that they can surpass the effects of sociospatial, economic and political peripherality.

Although the Mabopane Station precinct has a limited presence of traders from the Indian sub-continent and China (unlike in the former KwaNdebele and Rustenburg areas), traditional doctors from other parts of Africa connect Mabopane Station to their operations elsewhere in South Africa and to their medicine supply sites in Swaziland, Kenya, Nigeria, Botswana and Uganda. Having lived in places like Dubai, Ethiopia, Kenya, Khartoum, migrant traders (traditional doctors) add to the Station's cultural diversity, and despite their susceptibility to xenophobia, they are assertive in their trade, using the titles Doctors or Professors in advertising their overstated capabilities through pamphlets. Together with other informal traders, they also use stronger materials such as bricks and corrugated iron roofing to construct their shops. Nonetheless, reports of all informal traders' rooftops being ripped off at night to steal trading goods are common. As it is the case with those in KwaMhlanga, Phola and Kwaggafontein, they use these materials because the chances of them being evicted and their structures being destroyed are limited by relaxed local land management systems. In contrast, Rustenburg's land governance systems are strict; thus, in case they may be evicted and their structures destroyed, informal traders in Rustenburg use temporary materials such as plastic, sheet iron, packing cases, wood or traditional mud-brick. While many informal traders are temporarily located within and just outside the Station area, others locate along the M17 road on the Mabopane side, where they are happy that this location exposes them to customers-pedestrians and in vehicles. Again, the Mabopane Station precinct is a resource for commuters and residents.

They arrive at the Mabopane Station on inbound trips for work, for transit, shopping and for other commercial and public services at the Station precinct. They are from Pretoria and its surrounding areas; from different parts of the northern Gauteng city region periphery (including Makapanstad, which is $40 \mathrm{~km}$ away in the North-West province); from Johannesburg; and from as far as Thokoza in the City of Ekurhuleni. Most arrive by minibus taxis, with smaller but significant proportions arriving by train, walking and by bus. The Mabopane Station is also an origin and transit point for those who take outbound journeys to Pretoria, Johannesburg and Ekurhuleni (Author, et al., 2018; see Fig. 5). In this sense, it is a centre of the broader, conjectural, and transversal networks from which movement itself become space (Malaquais, 2007); through which Olga "wishes the trains were still running" (Howe, 2021: 12). The content of this popular centrality is seen in the hardships highlighted above and in the resilience of commuters as they switch between different modes of transport in order to safeguard arriving on time at work, while reducing the costs of travel. I have observed commuters in the train refusing to show their fare-tickets to train officials because they simply did not purchase them. The train 


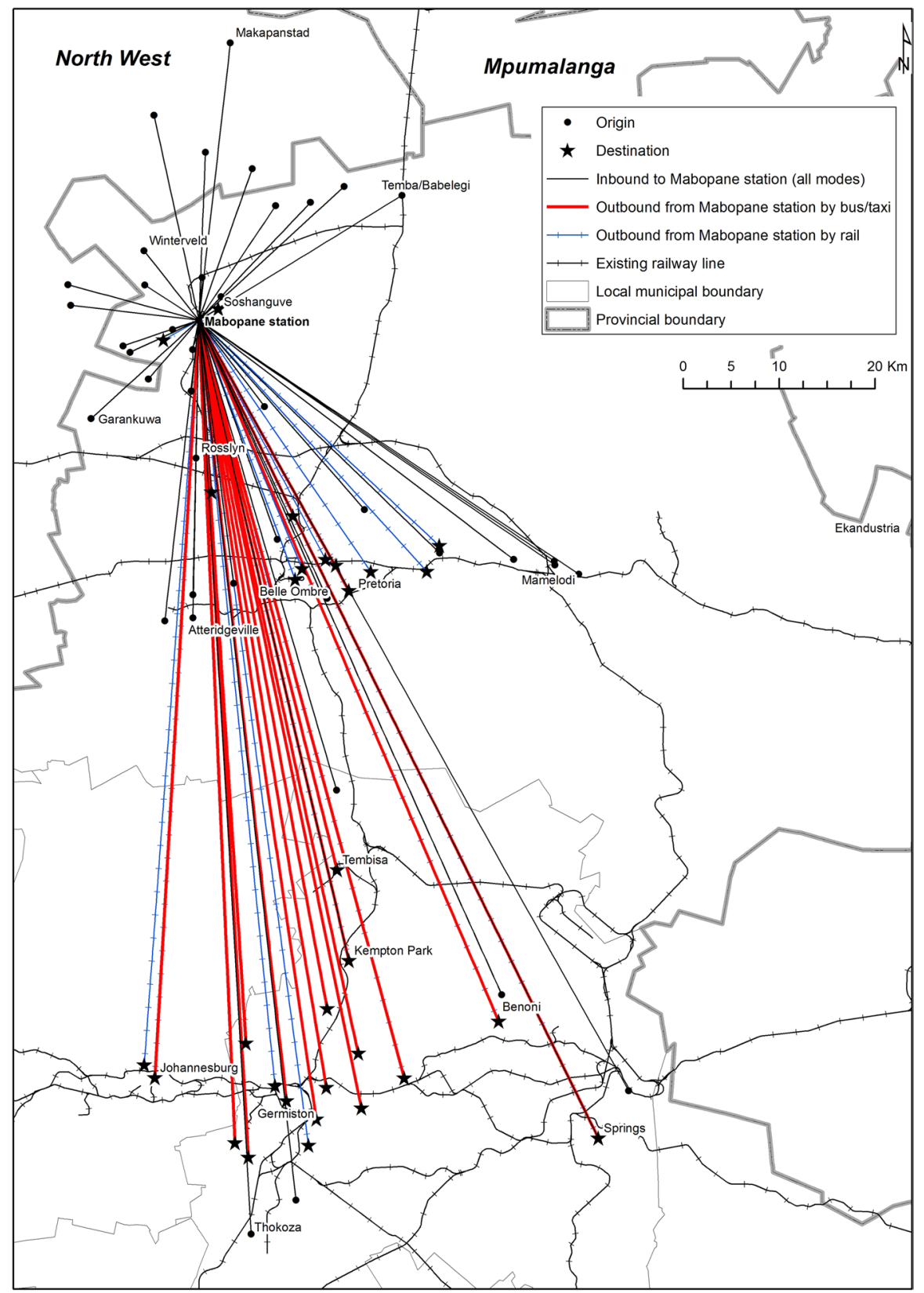

Fig. 5 Daily commutes throughMabopane station. DATA SOURCE: Demacon and GCRO; map by Ngaka Mosiane, SamyKatumba and Rethabile Sibisi

attendants have increasingly become afraid of enforcing that requirement due to security risks in the trains. Commuters evade payment of fares, using unauthorised entry and exit points at stations such as Belle Ombre and the Mabopane Station. 


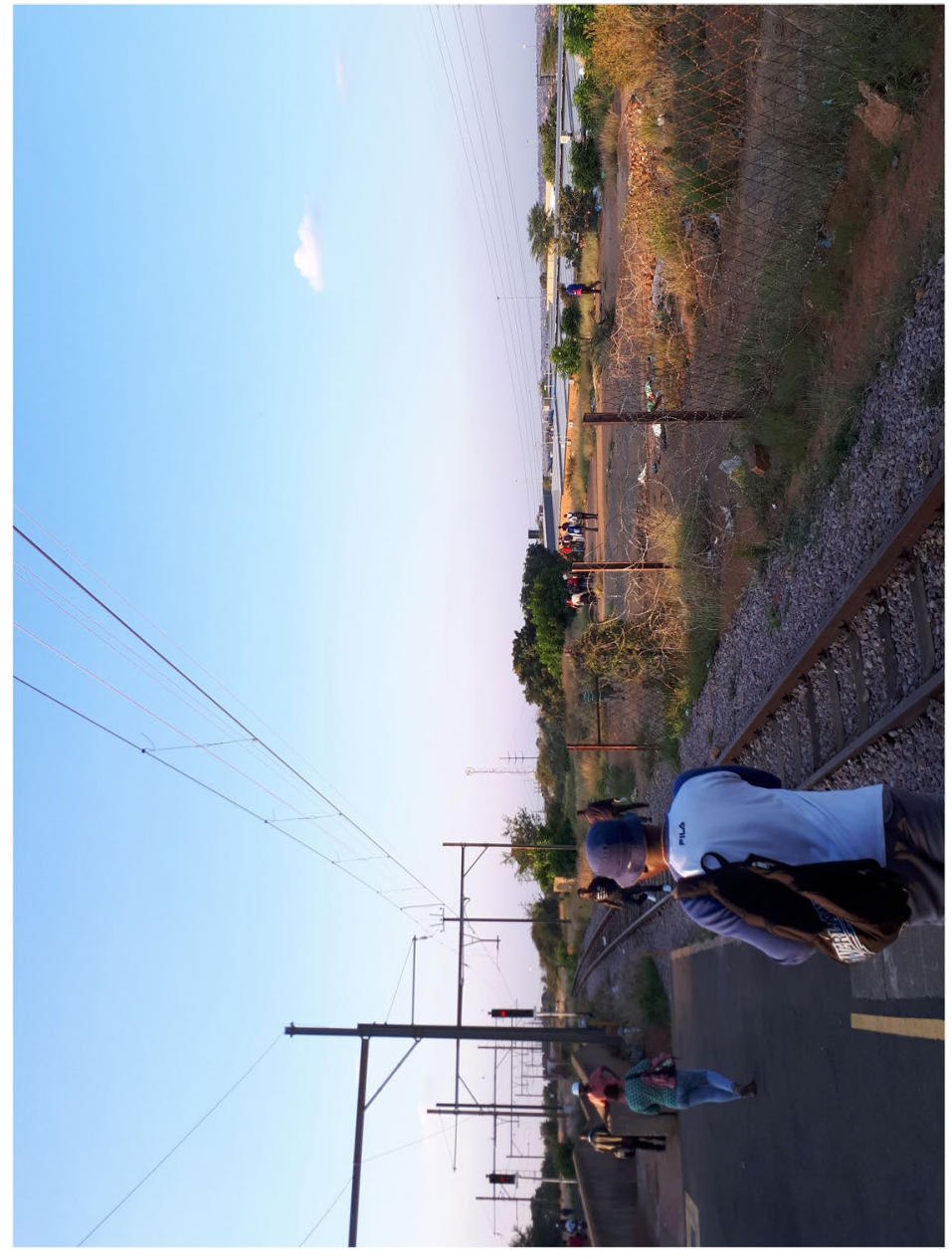

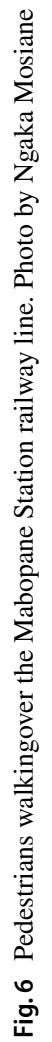


Traveling free of charge is a self-created form cross-subsidisation. Additionally, I observed the resilience of commuters chanting political slogans in particular train coaches, while they reserve other coaches for singing Christian Evangelical and Charismatic songs and preaching gospel. They set aside the front and rear coaches for occupation by smokers and drinkers of alcohol. Olga's male counterparts tend to squeeze themselves into overcrowded trains; infiltrating spaces for locomotive drivers; latching onto the exterior of coaches; and sitting on the train floor during an hour long trip. Female passengers such as Olga cannot easily engage in these desperate measures, and end up having to wait longer for other trains that are not overcrowded.

Given that the police services in the area are not particularly effective, communities and commuters came up with a number of mechanisms to deal with the safety issues raised above. In addition to natural surveillance, various neighbourhoods across the Mabopane, Soshanguve and Winterveld areas launched patrol services to protect commuters and pedestrians walking between their homes and the local bus/taxi stops as well as the Station. The patrols walk around neighbourhoods from 02h00, blowing a sound scattering plastic horn (vuvuzela) for walkers to join the escort. Households voluntarily pay a minimum of R10 per week. Informal traders at the Station precinct also introduced patrol service. A patroller said that "we decided to protect our customers". Each week, informal traders pay about R10 for Station patrollers, who work closely with the police. Patrollers do not use guns, but in order to tame muggers, they apprehend and whip them on their buttocks only, not on the face or other parts of the body. They then take muggers to the South African police in the Mabopane Station precinct, although they note that a mugger is often released in two days. As a result of the work of the Station patrollers, muggings only happen at night when patrollers are off-duty, from $20 \mathrm{~h} 00$ and around $02 \mathrm{~h} 00$.

Despite the challenges to making a living and living on the vicinity, the value of the Mabopane Station precinct and the resourcefulness of its people can be bolstered by creating a seamlessly integrated street network to facilitate local accessibility (more on this in the concluding remarks). In the context where the existing railway line linking northern Tshwane to Pretoria as well as the N4 and N1 roads allowing this northern Gauteng city region periphery to be largely accessible, the bottom-up safety initiatives and that seamless street network can untap the socioeconomic potential of the Mabopane Station precinct. This is even more possible given that the City of Tshwane has built on the Station renovations by PRASA, creating a multi-modal transport facility, which can turn the broader precinct into a sustainable urban core. In this sense, the Mabopane Station precinct renovations and rebuilding can add to an emergent urbanism of self-realisation referred to earlier. Although those interventions seem to be undermining that urbanism by displacing informal traders away from the Stations' lucrative sites (especially the concourse), commuters, residents and informal traders there remain resourceful, coping with their condition of socio-spatial, economic and political peripherality or even overcome it (Mosiane and Götz, 2021). Mabopane Station precinct redevelopment is separately carried out by the City of Tshwane, which has built the new Mabopane taxi rank, the Soshanguve rank for taxis and for the Public Utility Transport Corporation bus service (City of Tshwane, 2013). PRASA has upgraded the train 


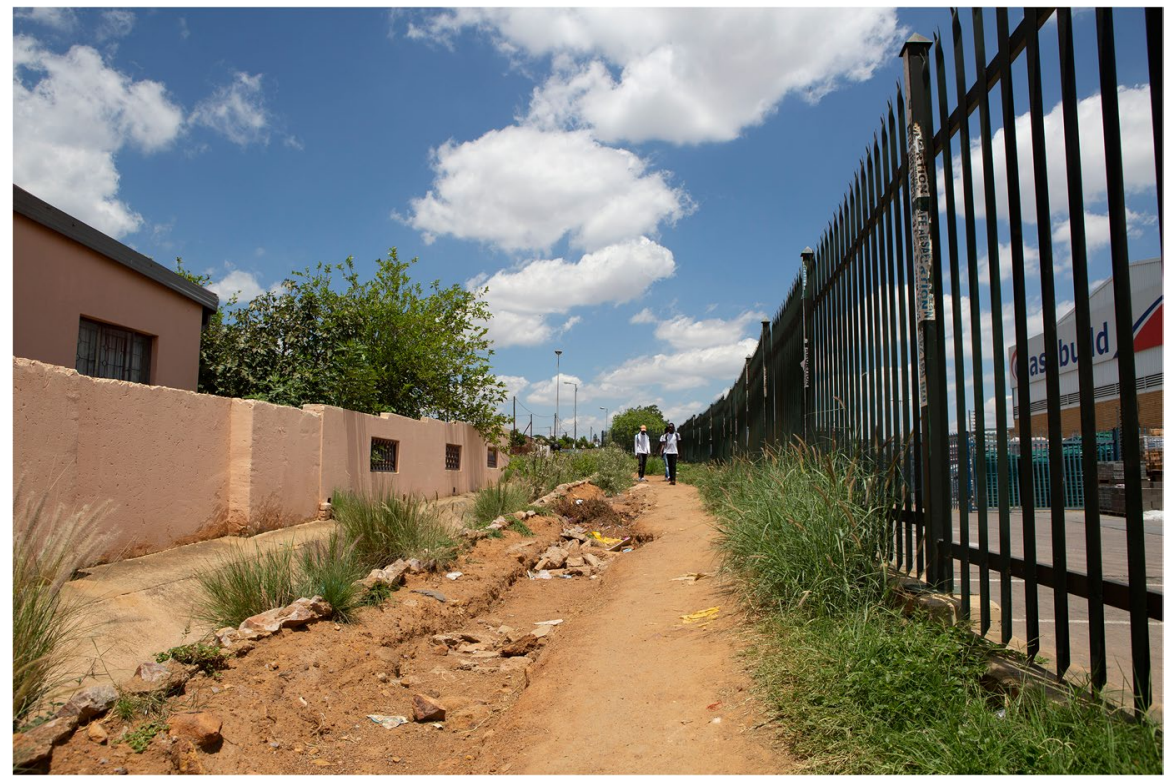

Fig. 7 The passage betweenSoshanguve Block AA and Soshanguve shopping complex 1 is dangerous topedestrians and commuters. Photo by Ngaka Mosiane

station, which includes the platforms for the North-West Star buses. The R274 million Mabopane train Station renovation-which excludes the R60 million spent by the City of Tshwane elsewhere in the precinct-is a fourth phase of a project launched in $2008 .{ }^{6}$ For the period of the Station improvement, informal traders were relocated across the Station precinct that is differently owned by PRASA, the City of Tshwane, the North-West Housing Corporation and a certain Mr Maponya. For those temporary arrangements, PRASA and the City of Tshwane variously provide lights, electricity, storerooms and toilets free of charge, although a significant number of informal traders operate outside these serviced areas. The revamped Station has a ground level area of $5949.39 \mathrm{~m}^{2}$ (the mezzanine). This total area splits into $4344,83 \mathrm{~m}^{2}$ of the concourse and $1604,56 \mathrm{~m}^{2}$ mezzanine (elevated) levels, excluding the foot-bridge attached to its northern side (see Fig. 8).

\footnotetext{
${ }^{6}$ Phase 1 involved the upgrade of sewerage facilities, water reticulation and storm water systems. It also included the refurbishment of the Metrorail ticket office, the construction of new access stairs and establishment of a new cash-in-transit area for Metrorail. Phase 2 focussed on installing 'fire prevention and detection systems', and decongesting the Station by constructing small- and medium-sized shops. It also saw the refurbishment of the taxi rank west of the station, which now includes a 383-bay holding area, a 58-bay pick up and drop off area, an ablution block and engineering services, including water, electricity and storm-water infrastructure. Phase 3 was characterised by the upgrade of the road network around the station to open up more land for development (Tancott, 2014).
} 


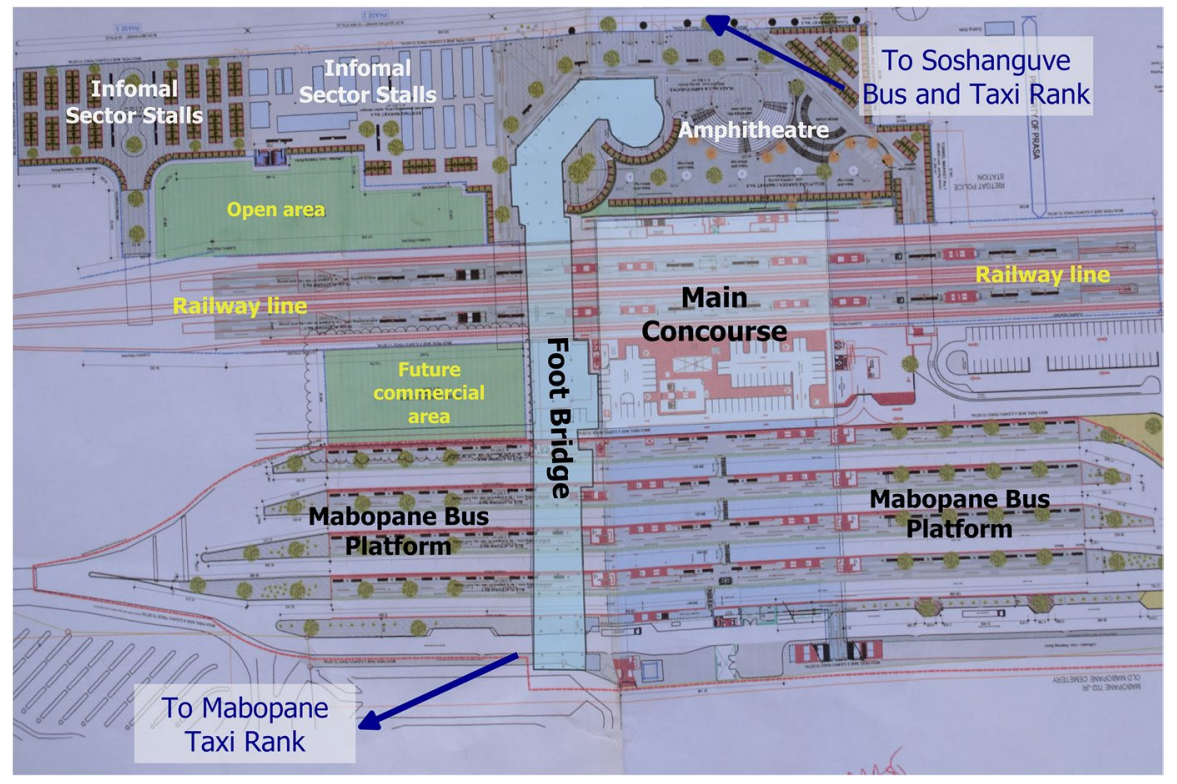

Fig. 8 The north-southMabopane train station renovation plan by PRASA. DATA SOURCE: PRASA; image byJennifer Murray and Ngaka Mosiane

The $2,300 \mathrm{~m}^{2}$ Spar supermarket (an anchor store) pays a monthly rent of $\mathrm{R} 90 / \mathrm{m}^{2}$. A $350 \mathrm{~m}^{2}$ cosmetic, health and personal care shop (Clicks) is a secondary anchor store, paying a bit more per month. In addition to the South African Police Services, smaller operations ${ }^{7}$ are charged a rent of $\mathrm{R} 150 / \mathrm{m}^{2}$. The foot-bridge was originally meant to accommodate 495 informal trading stalls $\left(3 \mathrm{~m}^{2}\right)$, paying R20 per day (R600 per month). It is now being rebuild after a shabby construction work, abandoned before completion. When it is completed, it will cross over the railway line as the thoroughfare linking the historically divided Mabopane in the west of the railway line and Soshanguve in its east. That foot-bridge will be $300 \mathrm{~m}$ long and $20 \mathrm{~m}$ wide. ${ }^{8}$ The spatial divide between the main concourse for formal businesses and the footbridge for informal trade means that the revamped Station has come to displace informal traders, with formal retail stores now occupying the lucrative central part of the Station which has higher levels of foot-traffic. This intervention of power is also seen in the informal sector stalls on the Mabopane side remaining informal,

\footnotetext{
7 These include Old Mutual, LK Movie Theatre, ZAR Sports Betting, DSTV Store, Multiserve, Hair Salon, Internet Café, Cellstore, Perfume Store, North-West Star Bus Services, D N J Bus Services, Autopax Bus Services and Peermed Medical Centre. The Food Court is comprised of Real Fish and Chips, Sausage Salon and the Glo-Bakery. The last two stores have been reserved for the local community members who will operate an African cuisine and Tshesanama restaurant. Although Kentucky Fried Chicken has a signed 'letter of intent', the franchisee is currently over-committed and unable to secure funds.

${ }^{8}$ National Treasury Tender Invitation, 2017: https://etenders.treasury.gov.za/content/mabopane-stationbridge-project-phase-2-rectification-defective-and-abandoned-construction).
} 
without any state built stalls; and the apartheid space is being reproduced through the current designs of the contracted bus services (the Public Utility Transport Corporation bus servicing the former South Africa - Soshanguve - while the North-West Star buses operate in the former Bophuthatswana). That said, the state interventions stand to consolidate the Station as a multi-modal transport facility, which can turn the broader precinct into an inclusive and sustainable urban core, not just a departure-transit-destination point.

\section{Conclusions}

This paper has demonstrated some of the constituent elements of popular centrality in northern Tshwane. Indeed, the popular agency's strategy of resilience is reproducing peripherality in the way it adapts to the existing socio-spatial, economic and political exclusions. It is reproducing it by switching between modes of transport to safe costs and to ensure arriving at work on time and through the use of patrollers for safe early morning and evening walks. That said, popular agency appropriates train coaches to intuitively and creatively reuse them for their purposes. That performance of popular centrality and popular agency is a significant part of the Mabopane Station precinct and its emergent urbanism of self-realisation. The latter is realised on the fissures of the precinct's shopping malls and complexes as well as the nearby Mabopane Unit $\mathrm{N}$ industrial areas. Informal trading there is part of the larger livelihood strategies and assets, which include social clubs and voluntary rotating-creditschemes as well as state entitlements (including state funded housing; social grants ${ }^{9}$; and municipal basic services). The residents make a living out of these strategies and assets; living in basic state provided housing; their own informal housing, while also expressing their aspirations for good life through creating modern and suburban-style housing architecture, land uses and other such activities. This emergent urbanism of self-realisation-being made real in the interstices of capitalist modernity — can be bolstered by all players in the Mabopane Station precinct, including local residents, who can ensure seamless interconnections among the precinct's streets, pedestrian passages, tunnels and bridges so as to serve the needs of pedestrians and vehicular mobility. That spatial design could generate socio-cultural and economic gains from land-uses along the routes lengths (Horner, 2012). This can be achieved through the land-use zoning and town planning controls used to shape the identity of a land parcel and the precinct's fine and course-grain mobility networks integrated to encourage walkability and vehicular accessibility. Although the overall carrying capacity of the local road infrastructure, those connecting this periphery to the broader Pretoria area (M35, R80, M39, M20, M21 and M17), the rail service and the N4 and N1 roads are insufficient, they all create accessibility to and from

\footnotetext{
${ }^{9}$ Recipients of social grants are paid the following amounts during the 2020/2021 financial year: R1050 for foster care; R460 for child support; R1890-R1910 for old persons; R1890 for care dependency; R1890 for disability; R1910 for war veterans; and R460 for Grant in Aid; R350 for Covid 19 Social Relief of Distress Grant (SRD).
} 
northern Tshwane. In varying and complementary ways, they can all improve the value of local land; harness the passing pedestrian and vehicular movements; and foster local enterprises. In the process, the Station projects stand to stitch together the historical ethnic divisions between Soshanguve and Mabopane (Tancott, 2014). The north-south block size of the Mabopane Station precinct is $6 \mathrm{~km}$ long, with no vehicular bridges connecting Mabopane and Soshanguve, but only a foot-bridge that will serve as pedestrian thoroughfare when it is completed. Therefore, increased accessibility into an area (vehicles and pedestrians) will further integrate these townships; boost the commercial value of the local land and thus benefit entrepreneurial activities. Those road and railway connections can further be used to anchor and strengthen the links among existing and new land-use functions: high-density mix of multi-purpose community centres, residential as well as commercial and retail activities within a predetermined walking radius of the Mabopane Station. In such an emergent urbanism, the outward-facing street perimeter activates the street and generates a vibrant street culture, where walkability and vehicular access themselves become an economic, socio-culturaland spatial value.

\section{References}

Ballard, R., Parker, A., Butcher, S. C., de Kadt, J., Hamann, C., Joseph, K., Mapukata, S., Mkhize, T., Mosiane, N., \& Spiropoulos, L. (2021). Scale of belonging: Gauteng 30 years after the repeal of the group areas act. Urban Forum, 32(2), 131-139. https://doi.org/10.1007/ s12132-021-09429-5

City of Tshwane. (2013). Mabopane Station Modal Interchange Design Development Stage 3: Detail Design Report Rev 1. Bryanston: Bosch Stemele (Pty) Ltd.

Chikengezha, T. \& Thebe, V. 2021. Living on the periphery and challenges of mobility: A tale if transport-induced social exclusion in Southlea Park, Harare, Zimbabwe. Urban Forum OnlineFirst article, https://doi.org/10.1007/s12132-021-09437-5

Coe, N. M., \& Jordhus-Lier, D. C. (2010). Constrained agency? Re-evaluating the geographies of labour. Progress in Human Geography, 35(2), 211-233. https://doi.org/10.1177/0309132510366746

Cresswell, T. (2006). On the Move: Mobility in the Modern Western Word. Routledge.

Cresswell, T. \& Merriman, P. (2011). Introduction. In T. Cresswell \& P. Merriman (Ed), Geographies of Mobilities: Praxtices, Spaces, and Subjects. Farnham: Ashgate Publishing Limited.

Czegledy, A. P. (2004). Getting around town transportation and the built environment in Post-Apartheid South Africa. City and Society, 16(2), 63-92. https://doi.org/10.1525/city.2004.16.2.63

Demacon. (2012). 'Research at selected flagship stations to produce and recommend optimal mix: Feedback presentation on Mabopane Station'. Menlo Park: Demacon Market Studies

Eriksson, R., Lindgren, U., \& Malmberg, G. (2008). Agglomeration mobility: Effects of localisation, urbasnisation, and scale on job changes. Environment and Planning a., 40(10), 2419-2434.

Gastrow, C. (2016). Aesthetic dissent: Urban redevelopment and political belonging in Luanda, Angola, Antipode, 49 (2), 377-396.https://doi.org/10.1111/anti.12276

Harrison, P., \& Dinath, Y. (2017). Gauteng - on the edge. In Uneven Spaces: Core and Periphery in Gauteng City-Region. GCRO Research Report, 6, 208-314.

Hattingh, P., \& Horn, A. (1991). Pretoria. In A. Lemon (Ed.), Homes Apart: South Africa's Segregated Cities (pp. 146-161). Paul Chapman.

Harvey, D. (2000). Spaces of Hope. Edinburgh University Press.

Horner, B. (2012). The Royal Bafokeng Nation: Cultural identity and spatial expression, Proceedings of the Eighth International Space Syntax Symposium, 2012. Edited by M. Greene, J. Reyes \& A. Castro. Santiago de Chile: Pontificia Universidad Católica de Chile. Paper ref \# 8067.

Howe, L. B. (2021). The spatiality of poverty and popular agency in the GCR: Constituting an extended urban region. Urban Geography, Online Print,. https://doi.org/10.1080/02723638.2021.1922200 
Katz, C. (2004). Growing up global: Restructuring and children's everyday lives. University of Minnesota Press.

Maharaj, B., Desai, A., \& Bond, P. (2011). Zuma's Own Goal: Losing South Africa's 'War on Poverty' (pp. 151-170). Africa World Press.

Marks, M. \& Overall, C. (2015). Breaking down walls: new solutions for more effective urban crime prevention in South African cities. Stability: International Journal of Security \& Development, 4(1), 1-19, https://doi.org/10.5334/sta.es

Malaquais, D. 2007. Douala/Johannesburg/New York: Cityscapes imagined. In M.J. Murray \& G.A. Myers (eds), Cities in contemporary Africa. London: Palgrave Macmillan.

McDonald, D. A. (2008). World city syndrome: Neoliberalism and inequality in Cape Town. Taylor and Francis.

McDonald, D. A., \& Pape, J. (2002). Cost recovery and the crisis of service delivery in South Africa. Zed Books.

McDonald, D. A., \& Ruiters, G. (2005). The age of commodity: Water privatization in Southern Africa. Earthscan.

Mosiane, N., \& Götz, G. (2021). Displaced urbanisation or displaced urbanism? Rethinking development in the peripheries of the Gauteng City-Region. GCRO Provocation. Johannesburg: Gauteng CityRegion Observatory.

Mosiane, N., Peberdy, S., Dzerefos, C., Sithagu, A. \& Murrary, J. (forthcoming). Landscapes of peripheral and displaced urbanisms. Johannesburg: Report of the Gauteng City-Region Observatory.

Parsons, N. 1995. Prelude to Difaqane in the interior of southern Africa c.600-c.1822. In C. Hamilton (ed.), The Mfecane Aftermath. Johannesburg: Wits University Press.

Peberdy, S. (2017). Uneven development - core and periphery in Gauteng, in S. Peberdy, P. Harrison and Y. Dinath, Uneven spaces: core and periphery in the Gauteng City-Region (pp. 21-200). Report of the Gauteng City-Region Observatory, Johannesburg.

Pierce, J., \& Lawhon, M. (2018). The right to move: Informal use rights and urban practices of mobility. Urban Geography, 39(5), 667-686. https://doi.org/10.1080/02723638.2017.1382050

Pieterse, M. (2019). Where is the periphery even? Capturing urban marginality in South African human rights law. Urban Studies, 56(6), 1182-1197.

Robinson, J. (2006). Ordinary cities: Between modernity and development. Routledge.

Robinson, J. (2004). Communities to Come: Re-making cities in a new South Africa. In E. Pieterse \& F. Meintjies (eds), Voices of the transition: The politics, poetics and practices of development in South Africa. London: Heinemann.

Royston, L., \& Budlender, J. (2016). Edged out: Spatial. Mismatch and spatial justice in South Africa's main urban areas. Socio-Economic Rights Institute.

Ruiters, G. (2011). Poverty research, oppression and 'Free Basic Water.' In B. Maharaj, A. Desai, \& P. Bond (Eds.), Zuma's own goal: Losing South Africa's 'war on poverty' (pp. 151-170). Africa World Press.

Tancott, G. 2014. 'Building an integrated city'. Infrastructure News and Service Delivery. Johannesburg: Institute of Municipal Engineering of Southern Africa

Turok, I., \& Parnell, S. (2009). Reshaping cities, rebuilding nations: The role pf national urban policies. Urban Forum., 20, 157-174. https://doi.org/10.1007/s12132-009-90060-2

Watts, M. (2015). Now and Then: the origins of political ecology and the rebirth of adaptation as a form of thought. In J. McCarthy \& T. Perrault (eds.). Handbook of Political Ecology. London: Routledge.

Wray, C. (2014). New spaces of transport in the Gauteng City-Region: A Gautrain analysis. In C. Wray, G. Götz, and C. Culwick Fatti, Mobility in the Gauteng City-Region, Report of the Gauteng CityRegion Observatory, Johannesburg.

Publisher's Note Springer Nature remains neutral with regard to jurisdictional claims in published maps and institutional affiliations. 